\title{
Cross-cultural adaptation and validation of the Rivermead Mobility Index in stroke patients within the brazilian cultural and language context
}

\author{
Karina Pavan', Luciana Carneiro Alaman da Cruz², \\ Michele Figueira Nunes², Liliam Gakiya Menezes², \\ Bruna Eriko Matsuda Marangoni ${ }^{1}$
}

\begin{abstract}
The aim of this project is to carry out the cross-cultural adaptation and validation of the assessment instrument known as the Rivermead Mobility Index (RMI) within the Brazilian cultural context and in Brazilian Portuguese for people suffering from strokes. The RMI was translated into Portuguese and translated back into English by independent bi-lingual translators, preserving the characteristics of the psychometrics in the original scale. After the formulation of the final version, a test and retest were carried out with an interval of one week. Ninety-five stroke patients took part in the study. The results obtained for sensibility, specificity and reliability were high We conclude that the Brazilian version of the RMI (RMI$\mathrm{BR}$ ) is a valid tool for Brazilian stroke patients.
\end{abstract}

Key words: stroke, validation studies, questionnaires.

\begin{abstract}
Adaptação transcultural e validação do instrumento Rivermead Mobility Index para pessoas com acidente vascular cerebral no contexto cultural brasileiro e português brasileiro
\end{abstract}

\section{RESUMO}

O objetivo deste estudo foi realizar a adaptação transcultural e validação do instrumento de avaliação conhecida como the Rivermead Mobility Index (RMI) no contexto cultural brasileiro e no Português Brasileiro para pessoas que sofreram acidente vascular cerebral. O RMI foi traduzido para o Português e retraduzido para o Inglês por tradutores independentes bilingues, preservando as características psicométricas da escala original. Após a formulação da versão final, teste e reteste foram realizados com intervalo de uma semana. Noventa e cinco pacientes que sofreram acidente vascular cerebral participaram do estudo. Os resultados obtidos para sensibilidade, especificidade e confiabilidade foram elevados. Nós concluímos que a versão brasileira do RMI (RMI-BR) é um instrumento válido para pacientes brasileiros com AVC. Palavras-chave: acidente vascular cerebral, estudos de validação, os questionários.

\section{Correspondence}

Luciana Carneiro Alaman da Cruz Rua Manguari 401 / Bloco C3 / apto. 21 02167-080 São Paulo SP - Brasil E-mail: lucianaalaman@yahoo.com.br

Received 24 June 2009 Received in final form 15 September 2009 Accepted 22 September 2009
The WHO - World Health Organization defines mobility as "the ability of an individual to move about freely and efficiently ${ }^{1}$. Being, as such, an essential characteristic for an independent life, its loss, after a stroke is considered by many pa- tients as a very serious deficiency ${ }^{2}$. After suffering a stroke, patients may present alterations in perceptuo-sensory, cognitive and sensory-motor functions such as muscular weakness, spasticity, abnormal types of movement and the loss of physi- 
cal condition. These impairments can limit the capability to carry out functional tasks, such as getting around (walking), use of stairs, practical life activities and selfcare $^{3}$. The Rivermead Mobility Index (RMI) ${ }^{4}$ is a tool that evaluates mobility, an important aspect of functionality in post-stroke patients and is becoming more and more used internationally for investigation amongst sufferers, due to it being a simple and quick evaluation that can be carried out at home, at work or in any institution and furthermore, for its appropriate psychometric properties ${ }^{4,5}$. It shows acceptable levels of reliability, validity and responsiveness for stroke patients in its English, Dutch and Italian versions $s^{5-10}$. The $R M I$ was developed and based upon the evaluation of gross motor functions, the first of three parts of the Rivermead Motor Assessment instrument proposed by Lincoln and Leadbitter in $1979^{11}$.

In rehabilitative medicine, tools capable of assessing activity and the completion of roles are essential in order to evaluate the evolution of patients over time and further to allow valid comparison between work carried out in different study centers spread around the world. To achieve this, it is necessary for such assessment tools to be not simply translated but rather adapted culturally to local needs and realities, such as to guarantee that the character of the original psychometrics are not lost in the translation ${ }^{12,13}$.

The objective of this project is to carry out the crosscultural adaptation and validation of the Brazilian version of the evaluation tool - the Rivermead Mobility Index (RMI-BR) within the culture and language of Brazil for patients suffering from strokes.

\section{METHOD}

A prospective cross-section study was carried out at the Irmandade Santa Casa de Misericórdia de São Paulo (ISCMSP) after approval from the Ethics Committee for Research upon Human Beings of the self same institution, number 232/08, with patients treated in the Rehabilitation Center and Intern patients of the Don Pedro II Hospital for Geriatrics and Convalescents (HGCDPII). All participants in the research expressed their consent through the signing of the terms of "willful knowing consent"

Ninety-five patients took part in the study, of which forty-four were from the rehabilitation center of the ISCMSP and fifty-one from HGCDPII. Those included in the study were patients above the age of eighteen years of age, being stoke patients, capable of understanding simple instructions, being excluded those patients that suffered from other associated neurological pathologies, such as cranial malformations and previous cranial trauma.

Tool - The RMI, developed by Collen et al. ${ }^{4}$ for the assessment of mobility, was translated into Portuguese as Rivermead Mobility Index (RMI-BR).
In order to make the cultural adaptations, the recommendations of Beaton et al. ${ }^{14}$ were observed, which require the translation and retro-translation by independent bi-lingual translators.

Preserving the psychometrics of the original scale, the Brazilian version of the RMI contains 15 items that comply with the criteria of Guttman ${ }^{4}$. For each item, there are two types of answers: $1=$ carry out and $0=$ do not carry out. The evaluator should ask each item and observe the execution or not of item 5 . The sum of the scores varies from 0 to 15 points, with higher scores indicating better mobility?.

After the final version of the scale had been formulated, the test and retest were conducted, with an interval of one week between them, for each patient and by the same evaluator.

\section{Statistical analysis}

The data obtained was analyzed through the Statistical Package for Social Sciences (SPSS) program, version 13.0. The characteristics of the sample and its effects upon the items analyzed were determined by means of the MannWhitney test for the variables of "gender" and "hemiplegia" and Spearman's correlation analysis for the variables: "date of injury" and "age".

The sensibility and specificity were calculated by means of the summary measures of descriptive statistics. While reliability was determined by means of an analysis of internal consistency using the Cronbach's alpha statistic test and the reproducibility was analyzed, based upon the data of the test and retest through Wilcoxon's Signed Rank Test. The results were considered significant when $\mathrm{p} \leq 0.05$.

\section{RESULTS}

Table 1 presents the demographic data and the characteristics of the sample. Gender, affected hemiplegia and

Table 1. Demographic data and characteristics of the test group.

\begin{tabular}{lc}
\hline Variables & Results \\
\hline Sex & \\
Male n (\%) & $56(59 \%)$ \\
Female n (\%) & $39(41 \%)$ \\
Hemiplegia & \\
Right n (\%) & $47(50 \%)$ \\
Left n (\%) & $44(46.80 \%)$ \\
Unknown & $3(3.20 \%)$ \\
Age ( in years) & \\
Average (standard deviation) & $61(12.3)$ \\
Average & 61 \\
Variation & 30 to 88 \\
Duration of condition (in months) & \\
Average(standard deviation) & $68.72(67.9)$ \\
Average & 48 \\
Variation & 1 a 316 \\
\hline
\end{tabular}


Table 2. Values of sensibility and specificity.

\begin{tabular}{ccc}
\hline Item & Sensibility & Specificity \\
\hline 1 & $100 \%$ & $100 \%$ \\
2 & $100 \%$ & $100 \%$ \\
3 & $100 \%$ & $87.5 \%$ \\
4 & $100 \%$ & $100 \%$ \\
5 & $100 \%$ & $100 \%$ \\
6 & $100 \%$ & $96.9 \%$ \\
7 & $100 \%$ & $100 \%$ \\
8 & $100 \%$ & $95.6 \%$ \\
9 & $100 \%$ & $94.9 \%$ \\
10 & $100 \%$ & $100 \%$ \\
11 & $100 \%$ & $100 \%$ \\
12 & $100 \%$ & $100 \%$ \\
13 & $100 \%$ & $100 \%$ \\
14 & $96.2 \%$ & $100 \%$ \\
15 & $93.3 \%$ & $100 \%$ \\
\hline
\end{tabular}

time of injury are variables that do not have an influence over the tested tool, whereas age showed interference in items: 7 test / retest $(\mathrm{p}=0.048 / 0.048), 10$ test / retest $(\mathrm{p}=0.04 / 0.04), 14$ test $/$ retest $(\mathrm{p}=0.003 / 0.004)$ and total score test/ re-test $(0.029 / 0.030)$ of the evaluated tool.

The values for sensibility and specificity presented in Table 2 were obtained by analyzing the test and retest and Table 3 demonstrates the result of the level of reliability.

The analyzed tool proved to have an acceptable reproducibility, based on the data from the test and retest, the results of which are presented in Table 4.

\section{DISCUSSION}

The use of the $R M I$ has been described internationally in articles, in order to evaluate mobility ${ }^{5,15}$. Furthermore, it is being translated and adapted into other languages to allow for comparison of results between studies conducted in different countries ${ }^{9,10}$. The report on the use of $R M I$ by Forlander e Bohannon ${ }^{15}$ and Rossier et al. ${ }^{16}$ suggests the growth of its usage in order to evaluate mobility, both in clinical practice and in studies. The adaptation and validation of this tool for Brazilian stroke patients will guarantee not only an excellent clinical appraisal tool, but further a means of comparison between our own studies and those conducted internationally.

In order to verify whether the RMI-BR preserves the psychometric characteristics, a detailed statistical analysis of the criteria and characteristics of the tool was required.

The correlation between the scale items and the age of the patients in our study sample showed statistical significant results for items 7,10, 14 and for the total score; these items being related to the unassisted walking and
Table 3. Internal consistency.

\begin{tabular}{cc}
\hline Item & Cronbach's alpha coefficient \\
\hline 1 & $>0.999^{*}$ \\
2 & $>0.999^{*}$ \\
3 & $0.963^{*}$ \\
4 & $>0.999^{*}$ \\
5 & $>0.999^{*}$ \\
6 & $0.988^{*}$ \\
7 & $>0.999^{*}$ \\
8 & $0.979^{*}$ \\
9 & $0.978^{*}$ \\
10 & $>0.999^{*}$ \\
11 & $>0.999^{*}$ \\
12 & $>0.999^{*}$ \\
13 & $>0.999^{*}$ \\
14 & $0.987^{*}$ \\
15 & $0.979^{*}$ \\
Totalizer & $0.999^{*}$ \\
\hline
\end{tabular}

${ }^{*} p<0.001$.

Table 4. Reproducibility through the test/retest data.

\begin{tabular}{cc}
\hline Pair of variables & Significance $(p)$ \\
\hline $1 R-1 T$ & $>0.999$ \\
$2 R-2 T$ & $>0.999$ \\
$3 R-3 T$ & 0.317 \\
$4 R-4 T$ & $>0.999$ \\
$5 R-5 T$ & $>0.999$ \\
$6 R-6 T$ & 0.317 \\
$7 R-7 T$ & $>0.999$ \\
$8 R-8 T$ & 0.157 \\
$9 R-9 T$ & 0.157 \\
$10 R-10 T$ & $>0.999$ \\
$11 R-11 T$ & $>0.999$ \\
$12 R-12 T$ & $>0.999$ \\
$13 R-13 T$ & $>0.999$ \\
$14 R-14 T$ & 0.317 \\
$15 R-15 T$ & 0.317 \\
$T R-T T$ & 0.334 \\
\hline
\end{tabular}

use of stairs without using the hand-rail. These activities required quite complex motor sensory functions from the patients, which can become altered by the natural aging process, as was affirmed by Maciel and Guerra ${ }^{17}$ on carrying out a study related to factors associated to mobility in the elderly. They observed that the majority of elderly people from the higher age brackets (particularly over the age of 75) proved to have a greater chance of showing 
mobility deficiencies as there is a reduction in the quality and quantity of necessary information for efficient mobility, such as proprioception, muscular strength and capsula-articular integrity.

The advanced age in itself just one factor that interferes in the mobility of patients. Our sample fitted into this description (an average and mean age of 61) without this, however, diminishing the sensitivity, specificity and reliability of the tool.

The levels of sensibility and specificity that were calculated showed themselves to be greater than $87 \%$ for all items, proving the efficiency of the instrument in terms of the test and retest. These results are confirmed by statistical analysis for internal consistency and reproducibility, the results of which are high and similar to those found documented, as we shall discuss below.

The values for Cronbach's alpha may vary from 0 to 1.000 , those higher than 0.700 indicating high reliability ${ }^{18,19}$. The figures for reliability are also high (between 0.963 and 0,999 , with $\mathrm{p}<0.001$ ), we may therefore infer that the data presented good internal consistency.

Such levels of reliability are similar to those found by Franchignoni et al. ${ }^{10}$ and Rooda et al. ${ }^{9}$, who found in their work on the validation of the RMI into Italian and Dutch a Cronbach Alpha coefficient of 0.93 and 0.97 respectively, an indication of excellent reliability.

The test and retest demonstrated high levels of reproducibility. Thus we found results similar to those of RMI to the Barthel Index, o Nottingham Extended Activities of Daily Living Scale and Frenchay Activities Index, in a study of 22 chronic stroke patients who were subjected to test and retest with a one week interval, and that concluded that the Barthal Index and the RMI are both reliable and reproducible and that the changes in score truly reflect any modification in the clinical condition of the patient.

In the present study, our option was to validate the RMI-BR just for stroke patients, given that the majority of international studies found recommended and use $R M I$ for such patients ${ }^{5-8}$ including the validations into other languages ${ }^{9,10}$ although other authors suggest that the RMI could be used for other conditions that present a loss of mobility, however, studies are still needed to prove that its characteristic hold with sufferers of other pathologies.

Despite our study not including chronic stroke patients, we believe that the RMI-BR could also be applied to this group, even though Rossier and Wade ${ }^{16}$ state that the $R M I$ may not adequately characterize the mobility of patients, in the initial phases of stroke conditions, particularly those with serious deficiencies. Antonucci ${ }^{6}$ carried out a study with 308 patients and concluded that the $R M I$ is a reliable and sensitive tool for the evaluation of stroke patients during the hospitalization and further for prior and post treatment in rehabilitation programs.
Our study showed that the RMI-BR is comprehensible, brief, and easy to both use and administer, and further useful in whatever environment, whether that be residential, ambulatory or within a hospital.

We conclude that the cross-cultural adaptation of the RMI-BR is a valid instrument (tool), which is both reproducible ans sensitive for the evaluation of Brazilian stroke patients.

ACKNOWLEDGMENTS - Dr. Sueli Luciano Pires, Technical Director of the HGCDPII, to Dr. Milton Luiz Gorzoni, Head of the Geriatrics and Gerontologia Department of ISCMSP and to Dr. Rosângela Ferro dos Santos, Head Physiotherapist for rehabilitation, HGCDPII, for allowing the evaluation of patients at HGCDPII, without which this survey would not have been possible.

\section{REFERENCES}

1. World Health Organization. International Classification of Impairment, Disabilities, and Handicaps: a manual of classification relating to the consequences of disease. Geneva: World Health Organization;1980.

2. Chiou I, Burnett CN. Values of daily living: a survey of stroke patients and their home therapists. Phys Ther 1985;65:901-906.

3. Teixeira-Salmela LF, Oliveira ESG, Santana EGS, Resende GP. Fortalecimento muscular e condicionamento em hemiplégicos. Acta Fisiátrica 2000;7: 108-118.

4. Collen FM, Wade DT, Robb GF, Bradshaw CM. The Rivermead Mobility Index: a further development of the Rivermead Motor Assessment, Int Disabil Stud 1991;13:50-54.

5. Green J, Forster A, Young J. A test-retest reliability study of the Barthel Index, the Rivermead Mobility Index, the Nottingham Extended Activities of Daily Living Scale and the Frenchay Activities Index in stroke patients. Disab Rehabil 2001;23:670-676.

6. Antonucci G, Aprile T, Paolucci S. Rasch analysis of the Rivermead Mobility Index: a study using mobility measures of first-stroke inpatiens. Arch Phys Med Rehabil 2002;83: 1442-1449.

7. Hsueh IP, Wang CH, Sheu CF, Hsieh CL, Comparison of psychometric properties of three mobility measures for patients with stroke, Stroke 2003;34: 1741-1745.

8. Chen HM, Hsieh CL, Sing KL, Liaw LJ, Chen SM, Lin JH. The test-retest reliability of 2 mobility performance tests in patients with chronic stroke. Neurorehabil Neural Repair 2007;21:347-352.

9. Roorda LD, De Kluis KRA, Molenaar IW, et al. Excellent cross-cultural validity, intra-test reliability and construct validity of the duth Rivermead Mobility Index in patients after stroke undergoing rehabilitation. J Rehabil Med 2008;40:727-732.

10. Franchignoni F, Tesio L, Benevolo E, Otonello M. Psychometric properties of the Rivermead Mobility Index in Italian stroke rehabilitation inpatients. Clin Rehabilit 2003;17:273-282.

11. Lincoln N, Leadbitter D. Assessment of motor function in stroke patients. Physiotherapy 1979;65:48-51.

12. Bussmann JB, Stam HJ. Techniques for measument and assessment of mobility in rehabilitation: a theoretical aproach. Clin Rehabil 1998;12:455-464.

13. Guillemin F Cross-cultural adaptation and validation of health status measures, Scand J Rheumatol 1995;24:61-63.

14. Beaton DE, Bombardier C, Guillemin F, Ferraz MB. Guidelines for the process of cross-cultural adaptation of self-report measures, Spine 2000;25:3186-3191.

15. Forlander DA, Bohanonn RW. Rivermead Mobility Index: a brief review of research to date. Clin Rehabil 1999;13:97-100.

16. Rossier P, Wade DT. Validity and reliability comparison of 4 mobility measures in patients presenting with neurologic impairment, Arch Phys Med Rehabil 2001;82:9-13.

17. Maciel ACC, Guerra RO. Fatores associados à alteração da mobilidade em idosos residentes na comunidade. Rev Bras Fisio 2005:9:17-23.

18. Churchil GA Jr. Marketing research: methodological foundations. $7^{\text {th }}$ Ed. New York: Inter. Thomson Publishing, 1995.

19. Yu CH. An Introduction to computing and interpreting Cronbach coefficient alpha in SAS. Proceedings of $26^{\text {th }}$ SAS User Group International Conference, 2001. 